Ю.В. Верба

\title{
ФИЛОСОФСКО-ПСИХОЛОГИЧЕСКАЯ ПРОБЛЕМА ЭКЗИСТЕНЦИАЛЬНОЙ ЖИЗНИ В РАБОТАХ Н.БЕРДЯЕВА, Г.МАРСЕЛЯ И В. ФРАНКЛА
}

\begin{abstract}
Аннотация. Экзистенциальная психология имеет богатые философские традиции. Живая человеческая экзистенция как активное, свободное, ответственное и при этом одухотвореное действие - главная тема исследований таких религиозно-экзистенциальных философов, как Г.Марсель, Н.Бердяев и В.Франкл. В данной статье рассматриваются осознания смысла понятий “быть» и "иметь» по отношению к человеческим экзистенциалам: тело, любовь, талант, вера у Г. Марселя и его объяснения жизни, смерти и бытия в целом как таинства; понимание свободы и несвободы духа, смысла творчества у Н. Бердяева; актуализированные Франклом понятия смысла, сверхсмысла и экзистенциального вакуума. В работе были использованы методы и подходы философской антропологии, экзистенциального и феноменологического анализа и герменевтики. Основным выводом данного исследования является то, что наследие экзистенциальных философов имеет несомненную ценность в практической работе экзистенциального психолога, особенно в современное время широкой распространенности ноогенного невроза (ощущения смыслоутраты). Для глубинного понимания самой сути человеческих проблем необходим экзистенциальный анализ и экзистенциальная психология, базирующаяся на философских осмыслениях.
\end{abstract}

Ключевые слова: смысл, экзистенциальная психология, экзистенциальный вакуум, философия практики, быть и иметь, духовность, таинство, свобода, творчество, вера.

Abstract. Existential psychology has very rich philosophical traditions. Alive human existence as an active, free, responsible and spiritual action is the main topic of researches by such religious and existential philosophers as Gabriel Marcel, Nikolai Berdyaev and Viktor Frankl. In this article Verba analyzes the definitions of the terms to be and to have in relation to human existentials such as body, love, talen, and faith in Marcel's works as well as his explanation of meaning, super meaning and existential vaduum. The author of the article has used methods and approaches of philosophical anthropology, existential and phenomenological analysis and hermeneutics. The main conclusion of the research is that the heritage of existential philosophers has a certain value for practical work of an existential psychologist, especially in our time when there is a so-called noogenic neurosis (loss of the meaning). To better understand the nature of human problems, it is necessary to carry out existential analysis based on the provisions of existential psychology and philosophy. Key words: faith, creativity, freedom, mystery, spirituality, to be and to have, philosophy of practice, existential vacuum, existential psychology, meaning.

$\prod$ сихолог, профессионал, претендующий на роль знатока человеческой души (психики) не может не быть философом. Например, вопрос, с которым все чаще обращаются пациенты к психологу: каков смысл жизни? - не просто психологический, но вековой философскийвопрос, относящийся кчеловеческому бытиюв целом и кчеловеческой душе.Зачем яживу? В чем смысл моей работы, отношений, творчества? Возможно ли жить гармоничной, целостной жизнью в этом сложном мире, где само бытие человека расколото? Можно ли посреди кажущейся бессмысленности столь краткого эмпирического существования обнаружить смысл, который сделает его наполненным, подлинным бытием? Все это философские вопросы. И для ответа на них психологу необходимы не только многочисленные знания об этом мире из разных областей, но и глубокое и широкое понимание человеческой природы и сущности. То есть, очевидно, что психологу нужна философия. Таким, во многом философским, направлением психологии является экзистенциальная психология, которая успешно соединяется с традициями философской мысли.

Зародившись еще в античности как учение о душе, психология постепенно теряла связь именно с этим центральным своим объектом, сосредоточившись главным образом на детальном исследовании ее (души, а точнее, уже не души, а психики) составляющих, или инструментах: память, мыш- 


\section{Психология и психотехника 12(99) • 2016}

ление, воображение, восприятие, эмоции, чувств и т.д. Изучение отдельных элементов нередко сопровождалось упущением из виду более широкой и целостной картины. Психология, оформившись в самостоятельную науку, отделилась от философии сравнительно недавно - в середине XIX века. И довольно долгое время в ней господствовал естественнонаучный подход, натурализм и позитивизм, оказавшие влияние, например, на бихевиоризм, редуцировавший душу до физического тела, объяснявший психику природной обусловленностью, наследственными механизмами, генетической программой, рефлексами, инстинктами и т.п. В настоящее время эта тенденция активно меняется. Так называемую классическую парадигму сменяет неклассическая. Психология становится все более гуманитарной наукой [1]. И экзистенциальная психология - яркий ее представитель. Во многом благодаря ей была актуализирована проблематика смысла, выбора, свободы, воли, ответственности, духовности. Фрагментарное изучение человека здесь отвергается. Человек определяется не системой психомоторных реакций, инстинктов, социальных ролей и других «механизмов», но своей духовной природой, тем, как он сам создает себя в этом мире.

Экзистенциальная психология уделяет большое внимание индивидуальности каждого человека в конкретный момент времени. Каждый человек здесь рассматривается по отдельности, в его уникальной неповторимости, ничто не сводится к общим правилам и законам «усредненного» человечества. При этом не упускается из виду неразрывная связь человеческой сущности с этим бытием. Экзистенциальный психолог не просто исследует человека как испытуемый объект, но вступает с ним в равноправный субъектно-субъектный диалог о насущных вопросах жизни, помогает непростому процессу становления личности. Об экзистенциальной психологии, как одном из направлений гуманистической, нередко говорится как о «психологии с человеческим лицом» [2].

В наше время все больше людей стало подвержено ноогенному неврозу (который В. Франкл называл состоянием экзистенциального вакуума), а именно: чувству смыслоутраты и непонимания путей его преодоления. Причем подвержены ему оказываются значительно развитые люди, достаточно образованные, имеющие многие знания и опыт, определенную житейскую мудрость. И весь этот огромный багаж знаний, умений, навыков бессилен заполнить их внутренний вакуум и дать ощущение бытийной, экзистенциальной полноты. Собственно, такого рода невроз нельзя назвать бо- лезнью в строгом понимании этого слова. Это скорее духовный, мировоззренческий кризис. Раньше духовным лечением занимались преимущественно религиозные наставники и школы, сейчас же многим образованным людям требуется «философское лечение».

В связи с заявленной темой особое внимание хотелось бы обратить на таких экзистенциальных философов как Н. Бердяев, Г.Марсель и В. Франкл. Их вклад в понимание особенностей человеческого бытия и человеческой природы - телесной и духовной - заслуживает дальнейшего внимательного исследования и выявления все новых «актуальных ракурсов экзистенциального освидетельствования человека» [3, с.5]. Названные авторы - настоящие знатоки философско-психологического целительства. И некоторые их «освидетельствования человека» - и творчеством, и собственной жизнью - мы осветим в данной статье.

В марте этого года (2017) на XXIII международной конференции Фонда единства православных народов, проведенной в Германии, было отмечено, что, например, в Нидерландах число запросов на эвтаназию значительно выросло (несколько тысяч в год), причем не только среди пожилых и неизлечимо больных, но и среди людей разного возраста, «чувствующих тоску и тревогу, утративших смысл жизни». На государственном уровне развернулась серьезная общественная дискуссия о предоставлении подобного рода эвтаназии (фактически официального разрешения самоубийства) всем желающим. Такие дискуссии ведутся также в Бельгии, Франции, Канаде и т.п. В России эвтаназия запрещена и публично практически не обсуждается, однако факты тайной эвтаназии подтверждаются анонимными опросами врачей. А по данным общероссийских опросов, очень много россиян занимают вполне лояльную позицию в этом вопросе. А также сохраняется по-прежнему высокий уровень самоубийств в развитых странах среди взрослых. Это, конечно, крайние примеры. Мы оставим здесь в стороне вопрос, как вообще могла развернуться подобная дискуссия на государственном уровне насколько должны быть либо бездушными, либо и сами находиться в состоянии экзистенциального вакуума и поэтому хорошо понимать весь его ужас, чтобы выступать «за» данное предложение. Но в целом налицо очень глубокий духовно-психологический кризис современных людей. Одно дело - неизлечимая болезнь, и совсем другое дело - экзистенциальный вакуум, приводящий человека к решимости свести счеты с жизнью или к поддержке других в такой решимости... А как много людей, не решаясь пойти на крайний шаг, продол- 
жает страдать от затяжных депрессий! По оценкам В03 во всем мире их число достигает 350 миллионов, к 2020 году депрессия возглавит список наиболее распространенных заболеваний, обогнав даже сердечно-сосудистые и онкологические. Это серьезная общественная проблема. И возникает насущная необходимость в психологах, которые могли бы помочь такого рода людям вновь обрести смысл существования, найти свое место в жизни. Простых знаний о человеческой психике в данном случае недостаточно. Нужен широкий и глубокий, подлинно философский взгляд на человека и мир.

Кстати, в свое время в общественной дискуссии вокруг проблемы легитимизации эвтаназии принял участие и философ-экзистенциалист Г. Марсель. Он был решительным противником такого «добровольного выбора человека», его якобы права распоряжаться своим собственным телом, своей жизнью, самим собой на правах хозяина. Он видел в таком выборе утрату человеческого достоинства, утрату ощущения сакральности жизни и видения «сверхвещности бытия». Тело по Марселю - «насквозь духовно», оно не только тело-объект, но и тело-субъект. С одной стороны, оно - «мое», и это часть меня, а с другой стороны - его происхождение сакрально, его естественное появление, существование и исчезновение управляемо некими превосходящими человеческое понимание законами. В нем находится наша душа, наш дух. И через бытие этого тела мы способны сообщаться с другими душами, находиться в непрестанном взаимодействии с ними. Поэтому к телу нельзя относиться как к простой вещи, которую при желании можно сломать и выбросить на свалку [4]. И также он отмечал, что самоубийство связано с потерей веры и надежды и неспособностью к служению. Самоубийство - это предельная реализация модуса «иметь» в противоположность модусу «быть» [5].

Традиционно считается, что понятие «экзистенциализм» восходит к латинскому «ехіstentia» - существование. Однако, например, Р. Мэй, известный американский экзистенциальный психолог, в своей книге «Экзистенциальная психология» возводит его к латинскому корню «ехistere» - «не сдаваться, подниматься на борьбу» [6]. И довольно емко выражает понимание бытия человека не как некоей совокупности механизмов психики или статичных моделей сознания, но как живое его существование, и что еще более важно - его возникновение, становление человеком. Это самое важное в экзистенциализме - человек существует именно тогда, когда он делает свободный выбор, формирующий его и его жизнь. Экзистенциальную психологию в связи с этим иногда называют «философией практики». «Человек есть не что иное, как то, что он сам из себя делает. Это - первый принцип экзистенциализма», - писал Ж.-П. Сартр [7].

Один из сущностных постулатов экзистенциальной философии: экзистенция предшествует эссенции - могут передать известные слова доктора Фауста из философской драмы Гете: «Вначале было Дело». Человек, будучи свободным, сам творит свою судьбу, каждый момент жизни принимая решения, делая свой выбор. И этот принцип лежит также в основе всего этого Бытия: оно сотворено скорее Делом, нежели Словом или Мыслью. Древний термин «логос» (лат.) в данном случае трактуется именно так. Хотя в духе экзистенциальной философии можно было бы перевести его и как Воля, и как Деятельная Любовь, или, как у В. Франкла, Смысл. Именно экзистенция как живое дело, деятельность «вдыхает жизнь в создание», формирует сущность человека, конструирует его судьбу и историю всего социума. И в этом процессе его внутренний мир, взгляды, представления непрестанно меняются, меняются его слова и мысли, изменяется его энергия (сила). Получается, что они - вторичны по отношению к экзистенции Дела. И постижение смысла жизни происходит в процессе деятельности, когда начинают проясняться ответы на вопросы: что, как и зачем делать.

У Г. Марселя есть интересные размышления на эту тему. Есть человек зритель, наблюдатель жизни, который словно просматривает свою жизнь как спектакль. А есть активный участник, «импровизатор» жизни. В первом случае жизнь фактически теряет смысл, ведь получается, что собственное Я отделено от его проявления в воплощенном мире, то есть оно как бы и не живет. Такое стороннее наблюдение может иметь смысл лишь тогда, когда подобная отрешенность осмысливается Я как «способ внутреннего участия», то есть опять же - действие. То есть всегда должна быть какая-то деятельность - либо внешняя, либо внутренняя. Без нее нет акта творчества жизни. Суть жизни раскрывается именно в таких актах: активных, с полным погружением, по-настоящему экзистенциальных [5].

С одной стороны, такой подход может показаться очень рациональным, практичным и прагматичным. Р. Мэй отмечал, например, что американцы на «ура» принимают слова Кьеркегора «Для индивида истинно лишь то, что он лично воплотил в действии» [6]. Но в повседневной реальности, так как человек - не запрограммированный робот, не машина - его действия никогда не могут быть полностью рациональны. Акт действия человека это всегда в той или иной степени акт творчества. Причем это касается не только поступков, которые 


\section{Психология и психотехника 12(99) • 2016}

он совершает своим телом, но и его речи, и даже мыслей. Произнесенное слово или продуманная мысль - уже становится «кирпичиком» в построении «дома» - личности человека. То есть, и мысль, и слово - в конечном счете, в духе экзистенциализма мы можем тоже считать делом. Творчество слова и мысли - с них начинается творчество деятельности. Не простая деятельность, а творческая, преображающая - одна из характерных особенностей именно человеческого существа, как отмечал Н. Бердяев [8]. Творчество - это то, что делает человека человеком, то, что от него ждет Бог (а не пассивного послушания). Подобно Богу как творцу мира, человек - Его со-творец в этом мире, который «оправдывается творчеством» [9]. Творчество человека - это не только некоторые виды искусства или науки, но гораздо более широкое понятие. Это акт свободного бытия, трансцендирование, выход из мира овеществленности, обыденности, объективации, из плена для духа. Дух возвышается над материей, личность превосходит косность материального мира своими деяниями. Творчество экзистенциальная основа человека.

Важно отметить, что многие представители экзистенциального направления философии и психологии сами являли собой пример целостной личности: их поступки формировали их как выдающихся личностей. Они переживали сложные экзистенциальные ситуации, в которых не шли на компромиссы с совестью, делали непростой, но сущностный выбор, изменявший их судьбы, совершали поступки, «пересотворявшие» их личность.

Как известно, Бердяев несколько лет провел в ссылке и четырежды был в тюрьме, пережил три войны, изгнание из родной страны был в ссылках и под арестом, а затем ему пришлось эмигрировать. В предисловии к одной из своих книг он писал: «Диалектика этой книги будет не логической, a жизненной, экзистенциальной диалектикой... Книга эта была написана в исключительно тяжелый период моей жизни и внешне и внутренне. Это относится к экзистенцальности творящего субъекта. Нужна большая духовная сосредоточенность, чтобы условия жизни не раздавили» [10]. Марсель потерял мать в четыре года, был очень слаб здоровьем, поэтому не мог пойти воевать во время Первой мировой войны, но он служил в Обществе Красного Креста, где нес тяжелую службу: общался с близкими погибших и пропавших без вести на фронте. Сам о себе говорил: «Философом экзистенции меня сделала война» [5], «Этот опыт истинно человеческого контакта с неизвестными людьми, опыт приобщения к их чувствам сыграл фундаментальную роль в разработке моей философии» [11].
Франкл во время Второй мировой войны прошел пять концлагерей, потерял всю свою семью. В концлагерях он, втайне от СС, занимался врачебной деятельностью, оказывая заключенным психологическую помощь, пробуждая в них волю к смыслу в тяжелейших физических условиях и психических состояниях. Непростой путь прошли Л. Шестов и К. Ясперс, который ввел понятие «пограничные ситуации», во многом опираясь и на личный экзистенциальный опыт болезни, драматических событий периода войны и власти нацизма (вынужденное прекращение работы в университете, постоянная угроза ареста). Самоотверженно жил и Б. Паскаль, сполна посвятивший себя наукам и философии, разорвав ради этого связь даже со своей любимой. Не нуждается в дополнительном упоминании жизнь Сократа, излюбленного мудреца для многих экзистенциалистов. На их жизненных примерах можно учиться экзистенциальному образу жизни: тесная связь философии и идей с реальной практической, повседневной жизнью.

Подобный целостный образ жизни присущ далеко не каждому человеку, включая и философов. Но именно такие примеры - яркая реализация самой сути экзистенциализма. Человек своей деятельностью сотворяет жизнь, которая в свою очередь сотворяет его личность. Личность и жизнь становятся едины. Особенно для экзистенциального психолога очевидное расхождение между жизнью и практической работой может считаться равнозначным краху его как профессионала. «Живите так, как я учу, но не живите так, как я живу» - совершенно неприемлемый лозунг, игнорирующий самую суть экзистенциализма.

Человеческое существо изначально очень рассогласованный, кажущийся неслаженным, живой «механизм», человеческое бытие «расколото» [12]. Природа и культура, сознание и бессознательное, инстинкты и осознанные действия, тело и дух. И как это проявляется в каждом дне жизни? Это рассогласованность воли, мыслей, слов, чувств и поступков. Говорим одно, делаем другое, поступаем как-то по третьему... И это переносится на все сферы жизни. Например, политика. Тот, кто должен быть по определению «слугой народа» и заверяет этот народ в том, что он прикладывает все усилия, чтобы улучшить его жизнь - по факту больше занят улучшением своей собственной жизни. Например, семейная жизнь. Люди клянутся в любви и верности друг к другу. А по факту не прикладывают усилий для взаимного понимания, страдают в отношениях и, в конечном итоге, расходятся, испытывая взаимную неприязнь. Так, в нашей стране разрушаются сотни тысяч семей в год, и два года 
назад ООН объявила Россию первой среди стран с самым высоким показателем уровня разводов. Редкие люди действительно могут сохранять отношения «и в горе, и в радости». Чаще при первых же трудностях пылкая любовь сменяет место не менее сильному раздражению и убеганию от личной ответственности под видом взаимных обвинений.

Экзистенциальная жизнь означает ответственное ее построение. Если в твоих ценностях есть любовь - ты привносишь ее во все жизненные ситуации и отвечаешь за то, если она исчезает из твоих поступков, слов и мыслей. Например, если политик объявляет себя слугой народа - не означает ли это нести ответственность за свои действия в соответствии с этой идеей? Единство идей и жизни - своеобразный экзистенциальный идеал. Бердяев говорил о «конфликте человека не только с миром, но с самим собой» [8]. И нужно подчеркнуть, что это - главный, первичный конфликт, который нужно решить. Именно с него нужно начинать. Но чаще люди, раздираемые внутренними противоречиями, начинают бороться с окружающим миром, видя именно в нем причину своих страданий. Можно осуждать нечестных политиков, но не сами ли мы своим молчаливым согласием поддерживаем их, при этом продолжая ненавидеть и осуждать?..

Кстати, можно наблюдать интересный парадокс экзистенциального образа жизни: создавая себя, свою личность в ежедневном, далеко не всегда заметном для окружающих труде, - человек перестает осуждать внешний мир. Он может задавать вопросы о противоречиях и жестокостях этого мира, при необходимости он может даже бороться, желая изменить его к лучшему - но внутреннее осуждение пропадает, увеличивается понимание, великодушие, прощение, сострадание. Человеческая эссенция выстраивается в соответствии с высокодуховными идеалами. Ежедневный скромный, смиренный внутренний героизм - это экзистенциальный путь.

Можно ли это назвать терпимостью? Нужно быть очень осторожным в использовании этого понятия. Казалось бы, это качество однозначно относится к разряду положительных. Но ведь так легко принять за терпимость совершенно иной психологический феномен! Подробный разбор терпимости делает Г. Марсель [11, с.161-168]. Его экзистенциальный анализ выявляет неоднозначность данного понятия. Под маской терпимости могут скрываться лицемерие, ханжество, а также духовная слабость. Развитая личность может быть толерантной, но подлинная терпимость - это нечто большее. Она связана с глубокой рефлексией и пониманием того самого явления или объекта, в отношении которого осуществляется эта терпимость. Терпимость как подлинная нейтральность, как живое воплощение веры, силы духа, благожелательности - совсем не те равнодушие, конформизм, неприязнь и даже «скрытый макиавеллизм» [13], а также личностная несостоятельность, которые иногда под этим словом скрываются. Сохранить толерантность и при этом не потерять подлинную духовность в сложных ситуациях - вот что необходимо.

Лишь две вещи человек может практиковать всей своей жизнью: религиозную веру и философию [13]. По сути, любой человек имеет свою религию или философию жизни, даже если они не сполна осознаваемы ими. И тут нужно учитывать, что расхождение между ними порождает глубокий конфликт, и как следствие - различные виды неврозов, включая ноогенный. Только на первый взгляд такое расхождение не представляет большой проблемы. Человек как-то привыкает к собственной нецельности и продолжает жить. Точно также можно привыкнуть к неврозам и продолжать с ними жить. Но можно ли назвать такую жизнь настоящей жизнью?..

У Марселя есть одно очень емкое понятие recueillement, которое обычно переводят как «сосредоточенность». Но думается, более уместный перевод - «созерцание». Здесь имеется в виду некое «реальное освобождение, реальный отрыв от всякого опыта» [14]. Это не столько концентрация, сколько медитативное погружение, охват ситуации, в которой находишься, не плоско, а объемно, целостно. Это не просто однонаправленное внимание, но многомерный акт познания, необусловленный мышлением, включающий также интуицию. Разум тих, молчалив, но при этом переживание смысла, постижения бытия и себя в нем происходит в большей полноте. «Именно в тишине я могу постигать себя... Recueilement и таинство тесно связаны» [14]. Такого рода способ взаимодействия с реальностью Гете называл «уважительным наблюдением», при котором сознание и явление как бы взаимопроникают друг в друга. И именно в таком состоянии совершаются открытия.

Таинство - одна из важных характеристик экзистенциального восприятия реальности. Таинственны механизмы и самого созерцания, а также раскрывается тайна, суть какого-то явления. Обычное рациональное мышление очень фрагментарно. Расширение восприятие открывает новые перспективы. Это особенно важно, когда идет речь о нахождении смысла там, где он скрыт, неочевиден. Например, в безысходных, трагических, тяжелых случаях. 


\section{Психология и психотехника 12(99) • 2016}

Интересно, что у Г. Марселя антитезой «таинства» является «проблема». Так, сама жизнь может быть таинством, а может - проблемой. Эта антитеза очень глубока и многогранна. Прежде всего, в ней скрывается противопоставление метафизического и научного восприятия реальности, живой естественности и сухой рационализации. Классический научный подход к явлениям - субъектнообъектный. Говоря о чем-то как о проблеме - мы рассматриваем ее отдельно от нас самих, как некий объект, с которым надо иметь дело. Так, в науке субъективность человека не считается существенной, важнее беспристрастно провести эксперимент и решить проблему, получив более-менее однозначные результаты, сделав что-то непонятное и неизвестное - понятным и известным.

Каково же таинство? Это совершенно иное восприятие. При таинстве - неизвестен и загадочен любой феномен, и прежде всего - сам человек. Здесь невозможно вынести себя «за скобки», поставить себя «вне контекста», невозможно сделать вид, что это тебя не касается. Это радикальное отличие философии от науки, а также экзистенциального восприятия от обыденного: субъектно-объектные отношения отсутствуют. Тайна стирает границы между человеком и миром. Марсель приводит пример художника: в процессе творчества творец и его творение сливаются: и сам он сполна погружается в свое искусство, и искусство словно становится этим творцом. То же самое относится и к нашему бытию. Если мы погружены в это бытие, поглощены им - разве можно говорить о нем в третьем лице, как о чем-то постороннем, как о предмете, вещи, проблеме?.. Бытие как тайна принципиально отличается от бытия научного, формализованного, бюрократического. Жизни нужно вернуть ее сакральное измерение.

Таинством также являются Бог, любовь, смерть. К этим таинствам можно, конечно, подойти и научно, но это означает превратить тайну в проблему, выхолостить ее, разложить на составные элементы, лишить одухотворенности, овеществить и сделать объектом из ряда других. Вот есть феномен смерти. Смертью как проблемой занимаются, например, патологоанатомы. Но от этого смерть не перестала быть таинством. Эта проблема не разрешилась, не стала понятной. Можно объективизировать и расчленить труп - но понятнее ли от этого становится смерть? А чувство экзистенциального переживания перед лицом смерти - возможно ли его объяснить, померив пульс или измерив кровяное давление? Здесь вспоминается врач-бельгиец из рассказа Сартра «Стена», приставленный к трем смертникам для изучения их физического состояния: что он может понять о смерти?
Или таинство любви. Некоторые ученые пытаются рассмотреть любовь с чисто биологической, инстинктивной, а также химической и других точек зрения, сделав из любви проблему, объект. Рассматривают, какие выделяются гормоны при состоянии влюбленности, как они вызывают привыкание, подобное наркотической зависимости, когда и как рецепторы кожи передают импульсы в кору головного мозга, как работают инстинкты, связанные с репродуктивной системой, ит.п. Есть даже мнение, что любовь - это просто болезнь, отравление организма, вызванное гормональным «опьянением». Но действительно ли эти объяснения проясняют таинство любви? Или при этом ускользает сама суть, реальность этого феномена?

А разве не таинством является, такая, казалось бы, обыденная, вещественная субстанция, как тело? Тело - это то, чем человек включен в бытие, через что он с ним соприкасается. Невозможно сказать, что человек - это только тело, но и невозможно считать тело сполна своей собственностью, вещью. Оно живет, растет, стареет, болеет - независимо от нашего желания. Это таинственная изначальная данность, которой мы таким же таинственным образом когда-то лишимся. Тело - нечто гораздо большее, чем предмет обладания. Физиология, биология, медицина - никогда не дадут полных знаний о нем, тело всегда будет оставаться таинством.

Таким же образом и многие другие феномены не могут быть поняты лишь разумом. Всегда чтото остается ему недоступным. И здесь приходит черед вере, одному из важнейших экзистенциальных понятий. Как говорил Франкл, «Когда знание сдается - факел передается вере. ... если мы не можем ответить на вопрос интеллектуально, мы можем сделать это экзистенциально. Там, где интеллектуальное знание терпит неудачу, необходимо принять экзистенциальное решение» [15].

Есть обычное рациональное объяснение вере. Например, Франкл отмечал, что обычно вера - это «мышление минус реальность», однако в экзистенциальном понимании - вера - это «мышление плюс экзистенция того, кто верит» [16, с. 146]. Вера связана с интуитивным ощущением нечто, что превосходит ограниченную реальность человека, а вовсе не исключает ее. Она - неотъемлемое свойство человека как духовного существа, где духовность - это «трансцендирующая экзистенция» или «экзистирующая трансценденция» [3, с.15], связывающая бытие и то, что за его пределами. Особенно это касается веры в наивысший, конечный смысл жизни человека. Разница лишь в том, что религиозный человек верит в Бога, а для нерелигиозного 
человека это является верой в наивысший смысл. И эту веру нельзя «иметь». Это духовный процесс, неотделимый от человека, в котором можно только «быть», находиться в неразрывной связи с ним и быть погруженным в него.

У Г. Марселя Бог - это не некая постигаемая разумом первопричина всех феноменов, Он не познается рационально, Он - не «что», а «кто». Доказать Его Бытие невозможно, оно принимается с помощью веры. И в этом принятии важно не доказательство, а свидетельство, а именно тот внутренний опыт, переживание, не оставляющий никаких сомнений в Его присутствии, которое может раскрыться, например, через акт молитвы. Бог всегда рядом, и с ним можно говорить, сверяя свой путь и свои чаяния. Бог - это все Бытие вместе со всеми окружающими индивида людьми. Такое восприятие приводит к трепетному отношению ко всему миру, всем живым существам, с которыми ты сопричастен, ведь это - сам Бог в Его многочисленных проявлениях.

Кстати, надо заметить, что в современное время в науку все больше проникает постнеклассическая парадигма, и это явно свидетельствует о тупике подхода классической науки. Теперь и для ученых становится очевидной неразрывная связь между объектом, субъектом и средствами. Приходит время «очеловечевания» науки. А некоторые ученые, в том числе и представители естественных наук (например, квантовой физики), начали приходить в своих исследованиях к пониманию необходимости включения в научную теорию понятия Бог, и делаются попытки доказать его существование (Д. Бом, Э. Флю, М.Д. Рис, А.Акимов и др.)

А теперь попытаемся углубиться в рассмотрение очень важной темы в экзистенциальной философии и психологии, которую нельзя обойти вниманием. Она связана с антитезой «быть и иметь». Г. Марсель коснулся этой темы даже раньше, чем Эрих Фромм, благодаря которому она стала широко известной в психологии («Очерк феноменологии обладания» Марселя, вошедший затем в книгу «Метафизический дневник», был зачитан им в философском собрании в 1933 году). Быть и иметь - это два способа включенности человека в мир. Бытие - это творчество, сопричастность, свобода, солидарность, подлинность, искренность. Установка же на обладание - это отчуждение, изолированность, несвобода, неподлинность, неискренность, искусственность, существование. И это относится ко всему: к самому себе, к миру, другим людям.

Прежде всего, мы считаем, что обладаем телом. Начиная с тела-вещи, постепенно вещами для нас становится и всё остальное: имущество, деньги, мысли (интеллектуальная собственность), статусы, люди, с которыми мы соприкасаемся, включая родных и любимых. Таковы субъектно-объектные отношения человека с миром. Но в состоянии «быть» картина меняется. Теперь человек не может накапливать вещи, профессии и положения, людей, подобно деньгам в банке под проценты. Теперь это становится неотъемлемой частью его самого. Он уже не просто имеет мысль, но мыслит, не просто учится какой-то профессии - но творчески реализуется в ней, не просто «заводит» друзей и близких, но сотрудничает с ними, сопричастен им. То, чем человек обладает, даже может управлять им. Чем больше мы имеем вещей, тем больше вещи начинают иметь нас. Обладание порабощает человека. Тут вспоминается пример с Диогеном, кричавшим на корабле работорговцам: «Кто хочет купить себе господина?»

Эта антитеза заключает в себя множество других, выделенных Марселем. Например, мудрец и эксперт. Мудрец - бытийствует, эксперт - обладает. Эксперт - профессионал в какой-то области, он имеет знания. А мудрец не только обладает знаниями, он еще и живет по ним. Есть еще мыслитель и идеолог. Мыслитель - творит свою мысль, не будучи порабощенным ими. Идеолог - раб своих мыслей, он закабален какой-то идеологией, например, партийной, неспособен отойти от нее ни влево, ни вправо, вынужден развивать ее, даже при внутреннем несогласии. Разница этих двух отношений значительна.

Также есть два вида свободы: подлинная творческая и свобода как произвол. Как известно, сам Марсель редко касался политики, и по своим взглядам был близок к либералам. Но в его трактовке свободы прослеживается более глубокое проникновение в суть этого понятия, нежели свобода обычно понималась либералами (т.е. я свободен, ты тоже свободен, но наши свободы не должны пересекаться и мешать друг другу). Свобода Марселя - это выход за собственные рамки, диалог с другими, взаимодействие. В этой свободе нет и не может быть автономии, ведь то, что связано с бытием, не может быть отдельным, полностью независимым. От бытия невозможно абстрагироваться. «Поскольку мы находимся в бытии, мы находимся вне автономии» [5]. Обладать чем-то можно только для себя. Но бытие - выше сугубо эгоистических желаний. И подлинная свобода - всегда бытийна. А свобода как произвол - это следствие эгоистичного понимания, что мы принадлежим только сами себе.

О духовной силе и свободе есть очень интересные наблюдения Бердяева. Прежде всего, он разли- 


\section{Психология и психотехника 12(99) • 2016}

чал категории дух и душа. Вспыльчивость своего характера он объяснял наследственными факторами барского самодурства. Но при этом подчеркивал, что глубины духа ничего наследственного не имеют, в отличие от душевно-телесных свойств. В себе он замечал силу духа и слабость души. К недостаткам своих душевных проявлений он относил, например, сухость эмоциональной жизни, задавленность лиричности, неспособность выразить свою любовь к людям (хотя сполна проявлял ее к животным). Он чувствовал свою холодность в человеческих, душевных отношениях и «огонь» внутренней духовной жизни [8]. Данный психологический феномен весьма интересен для анализа современной повальной увлеченности «духовностью». Встречаются семьи, распадающиеся именно из-за духовных поисков одного из супругов (спектр духовных школ сейчас очень обширен: от сект Свидетелей Иеговы до кришнаитов и авторских «восточных» направлений под вывеской «йоги»), который начинает манкировать семейными обязанностями. Есть ли в этом подлинная свобода духа? Вряд ли. Скорее, серьезная психологическая проблема, нуждающаяся в исцелении. Личностное ядро здесь не укрепляется, а скорее размывается, человек уходит от ответственности, выставляя это как духовную силу, на деле же демонстрируя душевную слабость. Искать вечное в обход временному (куда включаются и отношения с родными и близкими), трансценденцию в отрыве от экзистенции - одна из тревожных тенденций времени. Понимание феномена «горение духа» у экзистенциального мыслителя Бердяева может отчасти помочь отличить подлинную духовную свободу, ответственность и смелость от лже-свободы, точнее рабства из-за душевной слабости и безответственности.

Свобода духа, считал Бердяев, может быть бунтарской. Человек может не признавать никакие авторитеты и власть над ним других людей, церкви, религии, государства, и даже самого Бога. Он может бунтовать против любых «гасителей духа». Свобода должна быть бескомпромиссной. Но эта свобода никогда не подразумевает безответственности. Потому что, прежде всего, имеется в виду именно внутренняя свобода - свобода философская, идеологическая, духовная, а в общественном плане свобода от мещанства и буржуазности как плененности материальным и пошлой обыденности. Эту тонкую грань между искренним, идущим из самого сердца, духовным бунтарством против обывательщины, и презрением, осуждением и даже ненавистью к самим обывателям - необходимо различать и не переступать. Неприязнь к каким-то качествам и неприязнь к человеку-носителю этих качеств - непростая дилемма для искателей духовности в современное время. Также далеко не простая задача для подлинного духовного порыва: против чего и за что бороться?.. «О достоинстве христианства и недостоинстве христиан» - статья Бердяева с таким характерным названием многое позволяет прояснить в данном вопросе.

Возвращаясь к антитезам категорий быть и иметь, рассмотрим отмеченные Марселям понятия талант и гений. Талант относится к категории обладания. Это нечто данное человеку, чем он может распоряжаться по своему желанию: может использовать или нет, или даже продать его! Но гений это бытие, это то, чем человек живет, это фактически он сам, это качественное (а не количественное) отличие от таланта. Гений совершает открытия, которых до него не было. Гений - врожденное качество, слитое с натурой данного человека. Говорится, что у каждого человека есть какой-то талант, однако гении рождаются редко. В отдельных случаях даже собственный талант может привести к серьезным психологическим проблемам, как это было в случае с героем одной из пушкинских «Маленьких трагедий» Сальери перед гением Моцарта. Но как много людей в современном обществе, которые даже не могут проявить свои таланты, не то, что развить, - и поэтому они всю жизнь занимаются нелюбимым делом, а также испытывают комплекс неполноценности и завидуют тем, кому это удалось. Здесь хотелось бы немного смягчить эту антитезу и подчеркнуть, что хотя и не каждый человек рождается гением, но каждый по-своему талантлив. В глобальном масштабе миру и не нужно много гениев. Достаточно одного, чтобы совершить какое-то открытие в какой-то области. Но дальнейшее развитие этих гениальных идей, их детализация и конкретизация - это уже дело талантливых людей, их творчества. Поэтому очень важно найти и развить именно свой талант для полноценной, экзистенциальной жизни.

Итак, жизнь человека сама по себе - это таинство. Не какое-то абстрактное, а близкое каждому человеку в каждом его дне. Отчужденность человека от мира, проявляющуюся в модусе обладания - необходимо преодолеть. Пока человек живет с желанием «иметь» - он никогда не ощутить полноты жизни, счастья и гармонии с самим собой. И будет продолжать оставаться «человеком из барака» нетворческим, несвободным, забюрократизированным, покорным винтиком бездушной машины - социальной системы. Однако и в этом непостоянном мире, где само это непостоянство обуславливает безудержное стремление к накоплению, реализации эгоистичных желаний, безнравственности 
на пути к личным удовольствиям - даже в этом мире возможно сделать личный выбор, основанный на высших духовных ценностях. Даже в таких условиях можно создавать, творить свою жизнь, стремясь к высшему смыслу, скрытому за будничной суетой, побуждающей поступать совсем иначе. И важные здесь понятия - верность и надежда. Верность - это приверженность, преданность и высшему невидимому смыслу, и тому образу жизни, который будет соответствовать собственным наивысшим идеалам. Жить в соответствии со своей философией. Такая верность в расколотом мире собирает человека, противостоит непостоянству жизни. За этим словом скрывается более глубокое философское понятие трансцендирование, или, как у экзистенциалистов - экзистенциальное трансцендирование.

В продолжении понятия таинства у Марселя интересно будет рассмотреть, как развивает идею о сверхсмысле человеческой жизни и вере в него В. Франкл. Человек, неспособный к внимательному созерцанию, видит в явлении только ту малую часть, которая открывается его глазам и которую способен обдумать ограниченный ум, опираясь на такой же обыденный опыт, хранящийся в памяти. Это подобно бедной собаке, которую вивесекторируют в лаборатории, из примера У. Джеймса, или несчастной обезьяне, которую снова и снова прокалывают, испытывая на ней средство от полиомиелита, из примера Франкла. Если бы они могли думать, как люди, то разве хотя бы на мгновение не сумели бы осознать, насколько героична их судьба, какая большая удача выпала им в жизни - пожертвовать собой ради науки, ради блага многих людей?.. Но в момент ощущения лишь боли и страданий не видно никакого смысла. Так и человек его ограниченный интеллект слишком мал, чтобы взглянуть в более широком масштабе, увидеть таинство смысла за всеми жизненными явлениями, и особенно болезненными [16, с. 141].

В своей книге «Человек в поисках наивысшего смысла» Франкл приводит наглядный пример с «поперечным сечением», которое ученый прорезает сквозь реальность: в нем может и не быть особого смысла, но нельзя исключить возможность существования других сечений. Вот на горизонтальной плоскости случайным образом расположены пять изолированных точек, между которыми не видно никакой связи. Однако вполне может оказаться, что эти точки связаны некоей кривой линией, которая проходит через невидимые вертикальные плоскости. То есть связь проходит через многочисленные измерения, невидимые простым взглядом, неосознаваемые простым рассудочным мышлением в одной лишь горизонтальной плоскости. Так и мы: стоит перестать ограничивать наше представление о мире лишь биологическим планом, расширить горизонт восприятия - сразу же созерцаемая картина увидится совершенно иной. То, что кажется непознаваемым в данный момент - не значит невероятно $[16$, с.145].

Итак, можно сделать вывод, что наследие экзистенциальной философской традиции имеет несомненную ценность в практической работе экзистенциального психолога. Особенно сейчас, когда людей, наряду с персональными тупиками собственной жизни, все больше начинают волновать и универсальные вопросы феномена смысла жизни как такового, когда феномен экзистенциального вакуума (ноогенного невроза) наблюдается в довольно широких масштабах.

В данной статье мы главным образом коснулись философских размышлений лишь трех выдающихся представителей экзистенциализма, выделив ряд идей, которых позволяют расширить арсенал психолога для помощи той категории людей, которые нуждаются именно в философскопсихологическом исцелении. Однако вклад других экзистенциальных философов (Паскаль, Кьеркегор, Сартр, Хайдеггер, Ясперс, Ортега-и-Гассет, Камю, Аббаньяно, Шестов) в понимании природы, сущности и психологии человека также неоценим и нуждается в более глубоком философско-психологическом осмыслении.

\section{Список литературы:}

1. Леонтьев Д. А. Неклассический вектор в современной психологии // Социальный конструкционизм и нарративный подход. № 1 (2), 2005. - С. 51-71.

2. Психология с человеческим лицом: Гуманистическая перспектива в постсоветской психологии / Под ред. Д. А. Леонтьева, В. Г. Щур. М.: «Смысл», 1997. - 335 с.

3. Фатенков А.Н. Экзистенциальная онтология: концептуальный эскиз. Учебное пособие. - Н.Новгород: Нижегородский госуниверситет, 2015. - 169 с.

4. Бурханов Р.А. Метафизика веры, надежды и любви Габриэля Марселя // Вестник Нижневартовского государственного университета, 2010. Вып. 2.

5. Марсель Г. Метафизический дневник. М.: Наука, 2005. - 587 с.

6. Мэй Р. Экзистенциальная психология. М.: Апрель Пресс\&ЭКСMO-Пресc. 2001 // [Электронный pecypc] URL: http:// ligis.ru/psylib/090417/books/meyro04/index.htm (дата обращения: 16.04. 2017). 


\section{Психология и психотехника 12(99) • 2016}

7. Сартр Ж.-П. Бытие и ничто: Опыт феноменологической онтологии. М.: Республика, 2000. - 639 с.

8. Бердяев Н.А. Самопознание. М.: АСТ, 2010. - 448 с.

9. Бердяев H.A. Смысл творчества. Опыт оправдания человека // [Электронный pecypc] URL: http://e-libra.ru/ read/194892-smysl-tvorchestva.html (дата обращения: 18.05. 2017).

10. Бердяев Н.А. Экзистенциальная диалектика божественного и человеческого. М.: АСТ, 2011. - 640 c.

11. Марсель Г. Опыт конкретной философии. М.: Республика. 2004, - 224 с.

12. Гуревич П.С. Расколотость человеческого бытия. М.: ИФ РАН, 2009.- 199 с.

13. Визгин В.П. Актуальность философской мысли Габриэля Марселя // Русский журнал. 2012. [Электронный ресурс] URL: http://www.russ.ru/Mirovaya-povestka/Aktual-nost-filosofskoj-mysli-Gabrielya-Marselya (дата обращения: 06.05. 2017).

14. Марсель Г. К трагической мудрости и за её пределы. [Электронный ресурс] URL: http://sbiblio.com/biblio/archive/ marsel_k (дата обращения: 16.04.2017).

15. Франкл В.Э. Человек в поисках смысла. М.: Прогресс. 1990. - 368 с.

16. Frankl V.E. Man's search for ultimate meaning. New York: Basic Books, A Member of the Perseus Books Group. $2000 .-200$ p.

17. Большанин А.Ю. Пустота и экзистенциальный вакуум: перспективы экзистенциальной терапии // Экзистенциальная традиция: философия, психология, психотерапия. № 19, 2011. - С. 12-34.

18. Клюева Н. В. Экзистенциальная традиция в психологическом консультировании: учеб. пособие / Н.В. Клюева, Н.С. Головчанова. Ярославль: ЯрГУ, 2009. -120 с.

19. Тульчинский Г.Л. Смысл и гуманитарное знание // Проблема смысла в науках о человеке (к 100-летию Виктора Франкла): Материалы международной конференции. М.: Смысл, 2005. - С. 7-25.

20. Великовский С.И. В поисках утраченного смысла. Очерки литературы трагического гуманизма во Франции / С. И. Великовский. - СПб.: Центр гуманитарных инициатив, 2012. - 271 с.

\section{References (transliterated):}

1. Leont'ev D. A. Neklassicheskii vektor v sovremennoi psikhologii // Sotsial'nyi konstruktsionizm i narrativnyi podkhod. № 1 (2), 2005. - S. 51-71.

2. Psikhologiya s chelovecheskim litsom: Gumanisticheskaya perspektiva v postsovetskoi psikhologii / Pod red. D. A. Leont'eva, V. G. Shchur. M.: «Smysl», 1997. - 335 s.

3. Fatenkov A.N. Ekzistentsial'naya ontologiya: kontseptual'nyi eskiz. Uchebnoe posobie. - N.Novgorod: Nizhegorodskii gosuniversitet, 2015. - $169 \mathrm{~s}$.

4. Burkhanov R.A. Metafizika very, nadezhdy i lyubvi Gabrielya Marselya // Vestnik Nizhnevartovskogo gosudarstvennogo universiteta, 2010. Vyp. 2.

5. $\quad$ Marsel' G. Metafizicheskii dnevnik. M.: Nauka, 2005. - 587 s.

6. Mei R. Ekzistentsial'naya psikhologiya. M.: Aprel' Press\&EKSMO-Press. 2001 // [Elektronnyi resurs] URL: http://ligis.ru/ psylib/090417/books/meyro04/index.htm (data obrashcheniya: 16.04. 2017).

7. Sartr Zh.-P. Bytie i nichto: Opyt fenomenologicheskoi ontologii. M.: Respublika, 2000. - 639 s.

8. Berdyaev N.A. Samopoznanie. M.: AST, 2010. - 448 s.

9. Berdyaev N.A. Smysl tvorchestva. Opyt opravdaniya cheloveka // [Elektronnyi resurs] URL: http://e-libra.ru/read/194892smysl-tvorchestva.html (data obrashcheniya: 18.05. 2017).

10. Berdyaev N.A. Ekzistentsial'naya dialektika bozhestvennogo i chelovecheskogo. M.: AST, 2011. - $640 \mathrm{~s}$.

11. Marsel' G. Opyt konkretnoi filosofii. M.: Respublika. 2004, - 224 s.

12. Gurevich P.S. Raskolotost' chelovecheskogo bytiya. M.: IF RAN, 2009.- 199 s.

13. Vizgin V.P. Aktual'nost' filosofskoi mysli Gabrielya Marselya // Russkii zhurnal. 2012. [Elektronnyi resurs] URL: http://www. russ.ru/Mirovaya-povestka/Aktual-nost-filosofskoj-mysli-Gabrielya-Marselya (data obrashcheniya: 06.05. 2017).

14. Marsel' G. K tragicheskoi mudrosti i za ee predely. [Elektronnyi resurs] URL: http://sbiblio.com/biblio/archive/marsel_k (data obrashcheniya: 16.04.2017).

15. Frankl V.E. Chelovek v poiskakh smysla. M.: Progress. 1990. - 368 s.

16. Frankl V.E. Man's search for ultimate meaning. New York: Basic Books, A Member of the Perseus Books Group. $2000 .-200$ p.

17. Bol'shanin A.Yu. Pustota i ekzistentsial'nyi vakuum: perspektivy ekzistentsial'noi terapii // Ekzistentsial'naya traditsiya: filosofiya, psikhologiya, psikhoterapiya. № 19, 2011. - S. 12-34.

18. Klyueva N. V. Ekzistentsial'naya traditsiya v psikhologicheskom konsul'tirovanii: ucheb. posobie / N.V. Klyueva, N.S. Golovchanova. Yaroslavl': YarGU, 2009. -120 s.

19. Tul'chinskii G.L. Smysl i gumanitarnoe znanie // Problema smysla v naukakh o cheloveke (k 100-letiyu Viktora Frankla): Materialy mezhdunarodnoi konferentsii. M.: Smysl, 2005. - S. 7-25.

20. Velikovskii S.I. V poiskakh utrachennogo smysla. Ocherki literatury tragicheskogo gumanizma vo Frantsii / S. I. Velikovskii. SPb.: Tsentr gumanitarnykh initsiativ, 2012. - $271 \mathrm{~s}$. 